\title{
Molybdenum carbide doped with nanostructured nickel for application in degradation of reactive dyes
}

\section{(Carbeto de molibdênio dopado com níquel nanoestruturado para aplicação na degradação de corantes reativos)}

\author{
S. L. A. Dantas ${ }^{1 *}$, Y. F. Gomes ${ }^{1}$, A. L. Lopes-Moriyama ${ }^{2}$, M. A. Correa ${ }^{3}$, C. P. Souza ${ }^{2}$ \\ ${ }^{1}$ Universidade Federal do Rio Grande do Norte, PPGCEM, Campus Universitário, Natal, RN, Brazil \\ ${ }^{2}$ Universidade Federal do Rio Grande do Norte, CT/PPGEQ, Natal, RN, Brazil \\ ${ }^{3}$ Universidade Federal do Rio Grande do Norte, D. Física, Natal, RN, Brazil
}

\begin{abstract}
Carbide-type ceramic materials such as nickel-doped molybdenum carbide have promising photocatalytic degradation activity. The addition of nickel to the molybdenum carbide aims to increase its reaction yield and also its characteristics. The objective of this paper was to study the photocatalytic activity of $\mathrm{Mo}_{2} \mathrm{C}$ and $5 \%$ and $10 \%$ nickel-doped $\mathrm{Mo}_{2} \mathrm{C}$ materials used for the degradation of the Maxilon Blue GRL 300 textile dye. The structural properties were characterized by X-ray diffraction and scanning electron microscopy. For the determination of band gap energy, diffuse reflectance spectroscopy was used. The samples of the photocatalysis tests were analyzed by UV-visible spectroscopy. The best reaction yield was observed for the 5\% nickel-doped molybdenum carbide sample in photocatalytic tests, reaching a yield of around $92 \%$ in the final concentration of the dye solution.
\end{abstract}

Keywords: molybdenum carbide, nickel, band gap, degradation.

Resumo

Materiais cerâmicos do tipo carbeto, como carbeto de molibdênio dopado com níquel, têm promissora atividade de degradação fotocatalítica. A adição de níquel ao carbeto de molibdênio visa aumentar seu rendimento de reação e também suas características. Este trabalho teve por objetivo estudar a atividade fotocatalítica dos materiais $\mathrm{Mo}_{2} \mathrm{C}$ e $\mathrm{Mo}_{2} \mathrm{C}$ dopado com 5\% e 10\% de níquel para a degradação do corante têxtil Maxilon Blue GRL 300. As propriedades estruturais foram caracterizadas por difração de raios X e microscopia eletrônica de varredura. Para a determinação da energia de band gap, foi utilizada espectroscopia de refletância difusa. As amostras dos testes de fotocatálise foram analisadas por espectroscopia $U V$-visível. $O$ melhor rendimento de reação foi observado para a amostra de carboneto de molibdênio dopado com $5 \%$ de níquel em testes fotocatalíticos, atingindo um rendimento em torno de $92 \%$ na concentração final da solução de corante.

Palavras-chaves: carbeto de molibdênio, níquel, band gap, degradação.

\section{INTRODUCTION}

In recent years, transition metal carbides have received considerable attention due to their high melting point, mechanical resistance, and thermal stability [1]. Furthermore, considering the electronic structure presented by these materials, transition metal carbides demonstrate catalytic activity in hydrogenolysis, hydrodeoxygenation, isomerization, and hydrogenation, helping to break $\mathrm{H}-\mathrm{H}$ bonds $[1,2]$. In this sense, some studies suggest the addition of $\mathrm{Ni}$ in molybdenum carbide $\left(\mathrm{Mo}_{2} \mathrm{C}\right)$ to modify the activity, selectivity, and formation of the carbide phase [3].

There are several methods for synthesizing transition metal carbides [4], for instance: carbothermal reduction of metal oxides with graphite in an inert environment

*suylanlourdes@hotmail.com

Dhttps://orcid.org/0000-0003-3306-2358
[5], electrochemical synthesis, graphite melting, thermal decomposition of oxometallic diethylenetriamine compound, oxide reduction by $\mathrm{H}_{2}$, and a mixture of $\mathrm{H}_{2}$ and hydrocarbons as cementing gas or other carbon sources [6]. One aspect of these processes is that the activation of carbon in the environment is thermodynamically favorable for the formation of carbide phases [7]. The production of molybdenum and nickel carbide from nickel and molybdenum oxides was studied using the programmed carburization method using a $\mathrm{CH}_{4} / \mathrm{H}_{2}$ gas mixture as a carbon source [8]. The results suggest that the addition of nickel decreased the carburization temperature with increasing surface area and significantly increased the catalytic activity in dibenzothiophene hydrodesulfurization [8]. In a study [9] with molybdenum and potassium-doped nickel carbide in the steam reforming of ethanol to produce hydrogen, the carbide was produced at a controlled temperature of $996{ }^{\circ} \mathrm{C}$ in a reactor with a flow of $20 \% \mathrm{CH}_{4}$ and $80 \% \mathrm{H}_{2}$ gas mixture 
for the carburization of the precursors. The composition of $\mathrm{Ni}_{24} \mathrm{Mo}_{74} \mathrm{~K}_{2}$ carbide carburized at $1071{ }^{\circ} \mathrm{C}$ was the most active in the production of hydrogen. The addition of potassium to the catalyst was effective for the cleavage of the O-H bond [9].

Over the past decades, nanometric materials have been widely used for high-efficiency photocatalytic applications. Heterogeneous photocatalysis is a process that involves the degradation of organic compounds through the formation of hydroxyl radicals on the surface of semiconductor materials by irradiation of sunlight or artificial light $[10$, 11]. The photocatalytic behavior of $\mathrm{TiO}_{2}$ supported by $\mathrm{Mo}_{2} \mathrm{C}$ in vapor phase decomposition of formic acid was studied, where $\mathrm{Mo}_{2} \mathrm{C}$ prepared with $\mathrm{TiO}_{2}$ increased the extent of photocatalytic decomposition exhibited by pure $\mathrm{TiO}_{2}$, with dehydrogenation and dehydration reactions occurring at the same time $[12,13]$. The highly efficient photocatalytic production of $\mathrm{H}_{2}$ with $\mathrm{TiO}_{2}$ using $\mathrm{Ni}\left(\mathrm{NO}_{3}\right)_{2}$ as an additive in aqueous methanol solution has been reported [14]. In this system, the $\mathrm{Ni}^{2+} / \mathrm{Ni}$ reduction potential $\left(\mathrm{E}^{0}=-0.23\right.$ $\mathrm{V})$ is higher than the $\mathrm{TiO}_{2}$ conduction band $(-0.26 \mathrm{~V})$ but lower than the $\mathrm{H}^{+} / \mathrm{H}_{2}$ reduction potential $\left(\mathrm{E}^{0}=0.00 \mathrm{~V}\right)$. This energy level structure favors the transfer of photogenerated electrons from the $\mathrm{TiO}_{2}$ to $\mathrm{Ni}^{2+}$ conduction band and the reduction of $\mathrm{Ni}^{2+}$ to $\mathrm{Ni}^{2}$, which could assist in the charge separation and serve as a co-catalyst for $\mathrm{H}_{2}$ generation. As a result, Ni-charged $\mathrm{TiO}_{2}$ obtained under optimal conditions could achieve an $\mathrm{H}_{2}$ generation rate as high as $2547 \mu \mathrm{mol} / \mathrm{h}$ $[14,15]$.

In this paper, the potential of photocatalytic degradation of $\mathrm{Mo}_{2} \mathrm{C}$ and $\mathrm{Mo}_{2} \mathrm{C}-\mathrm{Ni}$ through the degradation of the Maxilon Blue GRL 300 dye from the textile industry was studied. The addition of $\mathrm{Ni}$ to the $\mathrm{Mo}_{2} \mathrm{C}$ catalyst improved its photocatalytic performance.

\section{EXPERIMENTAL}

Pure $\mathrm{Mo}_{2} \mathrm{C}$ and $\mathrm{Ni}$-doped $\mathrm{Mo}_{2} \mathrm{C}$ with concentrations of $5 \%$ and $10 \%$ by weight of nickel were produced. The preparation of the precursor material and the production of carbides occurred in two stages: i) preparation of the precursor powder via wet synthesis; and ii) reduction/ carburization by gas/solid reaction of the material in a fixed bed reactor with a gas flow of $\mathrm{H}_{2}$ and $\mathrm{CH}_{4}$. Synthesis of precursors: ammonium molybdate (CRQ, 99\%) and nickel nitrate hexahydrate (Vetec, 99\%) were used as precursors. The nickel nitrate reagent was weighed to the proportions of $5 \%$ and $10 \%$ by mass of atomic nickel. The reactants were mixed in a beaker with $42 \mathrm{~mL}$ of deionized water at $80{ }^{\circ} \mathrm{C}$ with magnetic stirring [16]. After mixing of the reactants and complete evaporation of water, the resulting mixture was dried in a muffle furnace at $70{ }^{\circ} \mathrm{C}$ for $7 \mathrm{~h}$ [17]. Synthesis of the carbide material: the precursor material was synthesized in the fixed bed horizontal reactor at 700 ${ }^{\circ} \mathrm{C}$ during $2 \mathrm{~h}$ under a flow of $12.5 \mathrm{~L} / \mathrm{h}$ of $\mathrm{CH}_{4}$ and $237.5 \mathrm{~L} / \mathrm{h}$ of $\mathrm{H}_{2}$ at atmospheric pressure. Before reaction, the reactor was outgassed with argon gas with a flow of $10 \mathrm{~mL} / \mathrm{min}$ in order to remove contaminants. In the next step, the material was submitted to a heating rate of $5^{\circ} \mathrm{C} / \mathrm{min}[17,18]$. The gas space velocity (GSV) for the methane gas was $337.0 \mathrm{~h}^{-1}$, and hydrogen gas was $6401.6 \mathrm{~h}^{-1}$.

Material characterization: the structural properties were determined with an X-ray diffractometer (D8 Advance Davinci, Bruker) with $\mathrm{CuK} \alpha$ source. From the X-ray diffraction (XRD) patterns, it was possible to infer the size of the crystals of the powder. To study the morphology of the samples, a powder metallization was performed (K550x, Emitec), and the micrographs were obtained by scanning electron microscopy (SEM, LEO1430, Zeiss). The study of band gap energy of the carbide was performed using a UV-vis-NIR spectrophotometer (5G, Varian Cary) with an accessory for diffuse reflectance measurement. Reflectance spectra were obtained in the range of 200 to $800 \mathrm{~nm}$ at room temperature, using barium sulfate $\left(\mathrm{BaSO}_{4}\right)$ as the reference sample for reflectance measurements. Preparation of the dye solution: Maxilon Blue GRL 300 dye solution was prepared by weighing and dissolving the adequate mass in distilled water in order to achieve a final solution concentration of $50 \mathrm{ppm}$. The $\mathrm{pH}$ of the solution was adjusted from 9.0 to 2.0 by the addition of concentrated $\mathrm{HCl}$. Photocatalysis reaction: this reaction was performed in a homemade device consisting of a wooden box isolated from light. The reactor was a $25 \mathrm{~mL}$ volume transparent tube of borosilicate glass having a jacket for temperature control interconnected with a thermostatic bath. In a typical procedure, the $20 \mathrm{~mL}$ mixture of the dye solution with a mass of approximately $5 \mathrm{mg}$ of carbide was irradiated by three $150 \mathrm{~W}$ tungsten lamps separated at $120^{\circ}$ to each other and a distance of 12 $\mathrm{cm}$ between the lamp and the reactor. The reaction was kept at $45^{\circ} \mathrm{C}$ for $60 \mathrm{~min}$. At the end of the reaction, the resulting solution was centrifuged for $12 \mathrm{~min}$ at $10000 \mathrm{rpm}$ in order to separate the catalytic solid from the dye solution; then the liquid was analyzed with the UV-vis-NIR spectrophotometer [18] to determine the absorbance value of the sample [19].

\section{RESULTS AND DISCUSSION}

Structural characterization: carbide-like materials were produced, replicated and analyzed by X-ray diffraction (Fig. 1) using similar parameters employed in a previous study [16]. It was possible to identify the characteristic peaks of molybdenum carbide with orthorhombic structure (ICSD 18205) [2] on both $\mathrm{Mo}_{2} \mathrm{C}$ and Ni-doped $\mathrm{Mo}_{2} \mathrm{C}$ (5\% and 10\%) samples, featuring only $\mathrm{Mo}_{2} \mathrm{C}$ peaks. The peak at $2 \theta \sim 43.4^{\circ}$ was associated with the (111) plane of free carbon (PDF 00006-0675). The absence of the Ni peaks in the XRD patterns can be associated with the low dopant concentration and high grain boundaries [20-22]. In particular, it was reported that the Co oxide peaks emerge in the XRD pattern for systems in which the Co oxide concentration is higher than $40 \%$ in the $\mathrm{ZnO}$ matrix [22, 23]. For $\mathrm{Mo}_{2} \mathrm{C}$, according to the literature [3, 24-26], this catalyst has several phases with different conductivities; therefore, it can have an uneven distribution of surface charge. From the results of XRD 
analysis, the crystallite size $\left(D_{\text {hkl }}\right)$ was estimated using the Scherrer equation (Eq. A) and the Halder-Wagner-Langford (HWL) method [27], considering normal and integral methods for the determination of peak width.

$$
\mathrm{D}_{\mathrm{hkl}}=\frac{\mathrm{k} \cdot \lambda}{\beta \cdot \cos \theta}
$$

where $\mathrm{k}$ is the shape coefficient of the reciprocal network point (0.9-1.0), $\lambda$ is the wavelength of the radiation, $\beta$ is the full width at half maximum (FWHM), and $\theta$ is the angle of diffraction. Table I shows the crystallite size for the studied samples. The Scherrer model does not consider the microtension in the sample structure. On the other hand, the HWL model [27] is more comprehensive in terms of defects existing in the crystalline structures and approximates the true value of crystallite size more reliably. Comparing the values of crystallite size by the HWL and Scherrer methods for all studied samples, it was observed that there was an increase from the sample without doping in comparison with the Ni-doped samples, by using both methods. In particular, for the $\mathrm{Mo}_{2} \mathrm{C}-\mathrm{Ni} 5 \%$ sample, there was a variation in the crystallite size value calculated by the normal HWL method;

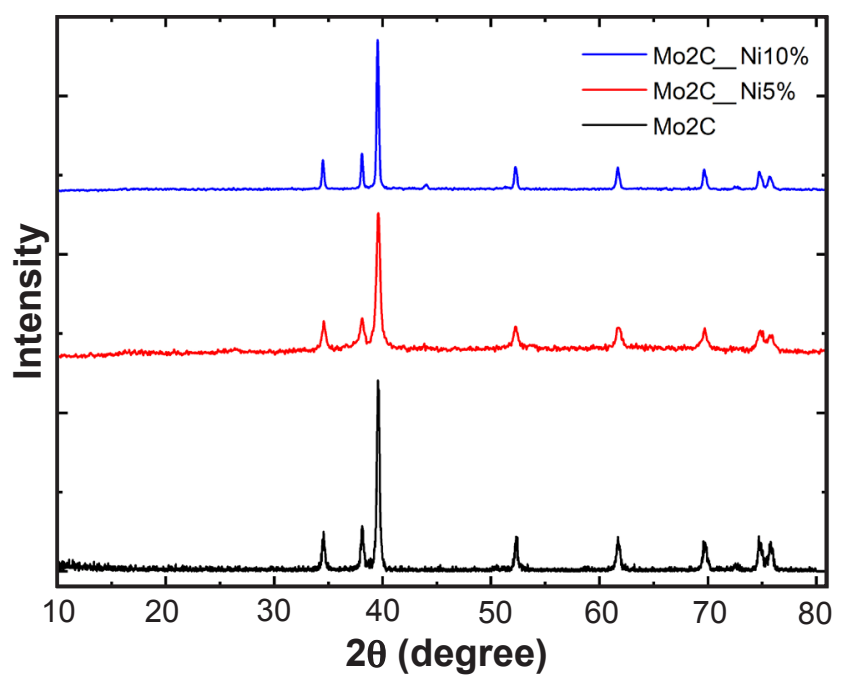

Figure 1: XRD patterns for undoped $\mathrm{Mo}_{2} \mathrm{C}$ and $\mathrm{Ni}$-doped $\mathrm{Mo}_{2} \mathrm{C}$ samples.

[Figura 1: Padrões de DRX das amostras de $\mathrm{Mo}_{2} \mathrm{C}$ e $\mathrm{Mo}_{2} \mathrm{C}$ dopadas com Ni.]

Table I - Crystallite size calculated from the Scherrer equation and HWL method.

[Tabela I - Tamanho de cristalito calculado a partir da equação de Scherrer e método HWL.]

\begin{tabular}{ccccc}
\hline \multirow{2}{*}{ Sample } & \multicolumn{2}{c}{ Normal } & \multicolumn{2}{c}{ Integral } \\
& $\begin{array}{c}\text { HWL } \\
(\mathrm{nm})\end{array}$ & $\begin{array}{c}\text { Sch. } \\
(\mathrm{nm})\end{array}$ & $\begin{array}{c}\text { HWL } \\
(\mathrm{nm})\end{array}$ & $\begin{array}{c}\text { Sch. } \\
(\mathrm{nm})\end{array}$ \\
\hline $\mathrm{Mo}_{2} \mathrm{C}$ & 34.7 & 28.9 & 23.5 & 19.1 \\
$\mathrm{Mo}_{2} \mathrm{C}-\mathrm{Ni} 5 \%$ & 43.7 & 32.4 & 27.3 & 24.1 \\
$\mathrm{Mo}_{2} \mathrm{C}-\mathrm{Ni10 \%}$ & 37.5 & 36.6 & 38.0 & 37.2 \\
\hline
\end{tabular}
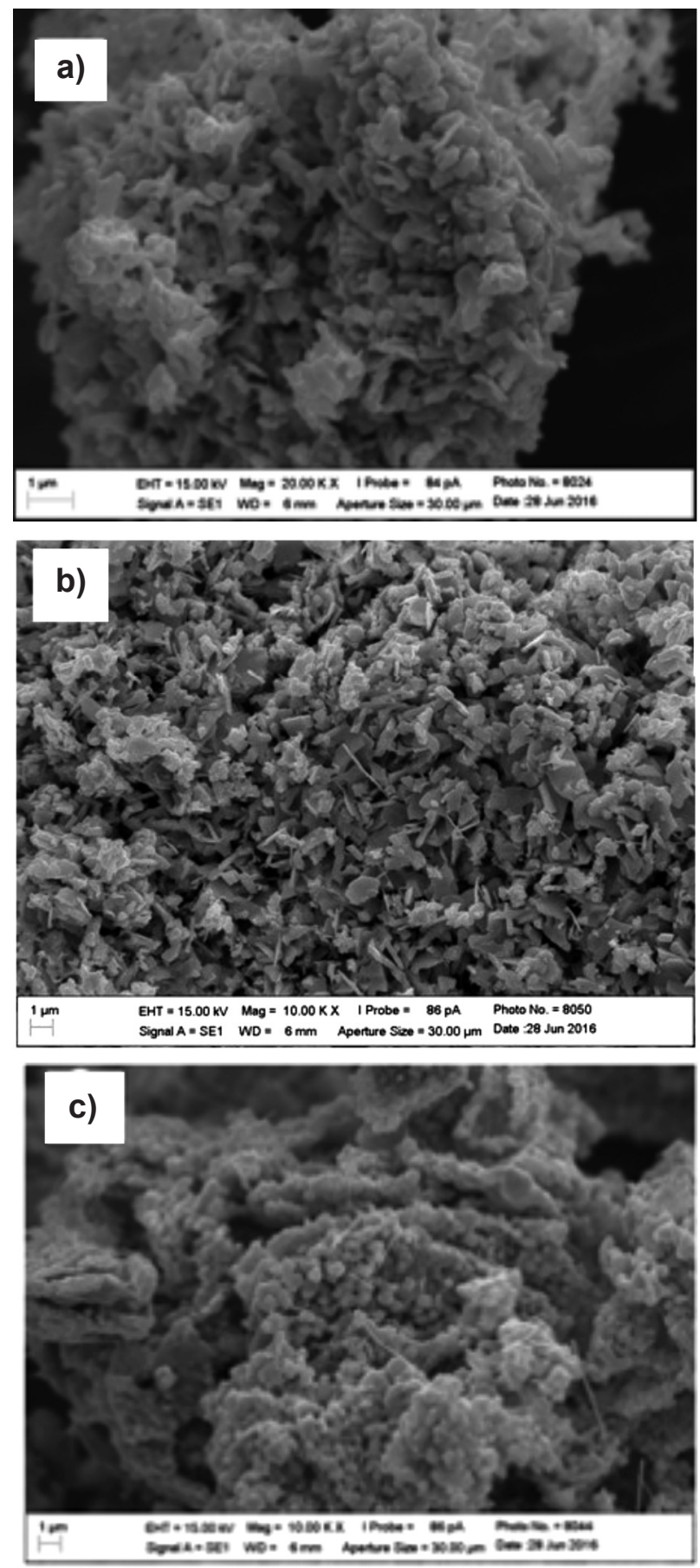

Figure 2: SEM micrographs for the samples: a) $\mathrm{Mo}_{2} \mathrm{C}$; b) $\mathrm{Mo}_{2} \mathrm{C}-\mathrm{Ni} 5 \%$; and c) $\mathrm{Mo}_{2} \mathrm{C}-\mathrm{Ni} 10 \%$.

[Figura 2: Micrografias de MEV das amostras: a) $\mathrm{Mo}_{2} \mathrm{C}$; b) $\mathrm{Mo}_{2} \mathrm{C}-\mathrm{Ni} 5 \%$; e c) $\mathrm{Mo}_{2} \mathrm{C}-\mathrm{Ni} 10 \%$.]

this behavior was related to a micro-deformation in the structure of this sample. Moreover, we considered that the $\mathrm{Mo}_{2} \mathrm{C}$ and $\mathrm{Mo}_{2} \mathrm{C}-\mathrm{Ni10} \%$ samples had similar values. At the same time, little or no micro-deformation and/or anisotropy in the samples were found in terms of the crystalline structure of the materials. This feature may be related to the efficiency of the doping method and the gas-solid reaction synthesis technique, reinforcing the concept that nickel was 
incorporated in the molybdenum carbide structure.

Scanning electron microscopy: SEM micrographs for the studied samples are presented in Fig. 2. In Fig. 2a, the molybdenum carbide morphology is presented, and it is possible to observe the agglomerates of the material. The morphology of $\mathrm{Mo}_{2} \mathrm{C}-\mathrm{Ni} 5 \%$ is presented in Fig. 2b; it is possible to observe the formation of particle agglomerates, mostly of platelets with heterogeneous sizes. In addition, the presence of rod-shaped particles was observed, related to the aggregation of the metallic nickel to molybdenum, causing grain growth. When comparing the micrographs of $\mathrm{Mo}_{2} \mathrm{C}-$ $\mathrm{Ni} 5 \%$ (Fig. 2b) and $\mathrm{Mo}_{2} \mathrm{C}-\mathrm{Ni10} \%$ (Fig. 2c), it was more evident the decrease in the particle size with the addition of $\mathrm{Ni}$ ions into the molybdenum carbide; the sample with $10 \%$ $\mathrm{Ni}$ showed spheroidal shaped particles in the great majority, attributed to the molybdenum carbide, and also the presence of some rod-shaped particles. The increase in $\mathrm{Ni}$ content on the samples led to a decrease in the mean particle diameter, indicating that the Ni played a catalytic role in the formation of $\mathrm{Mo}_{2} \mathrm{C}$ by gas-solid reaction [24]. The Ni-doping on $\mathrm{Mo}_{2} \mathrm{C}$ leads to a decrease in the average grain agglomerate diameter; a similar result was shown in a recent study reported by our group [23]. Here, Ni controlled the rate of the grain formation resulting in the formation of $\mathrm{Mo}_{2} \mathrm{C}$ cores, which coalesced at approximately the same rate. This mechanism led us to conclude that the rate of $\mathrm{Mo}_{2} \mathrm{C}$ formation was slower than the grain coalescence in the absence of Ni. These results were in agreement with the reaction conditions utilized (700 ${ }^{\circ} \mathrm{C}$ and atmospheric pressure). Through energy-dispersive $\mathrm{X}$-ray spectroscopy (EDX) coupled in SEM, it was possible to observe the homogeneous distribution of $\mathrm{Ni}$ in the entire sample and not only on its surface, indicating the absence of a biphasic composite. The results showed Ni content values close to those calculated in the experiments, reaching 5.88\% for the sample with $5 \% \mathrm{Ni}$ and $11.06 \%$ for the sample with $10 \% \mathrm{Ni}$, making these values acceptable according to the calculations performed.

Analysis of band gap: the calculation of optical band gap energies $\left(\mathrm{E}_{\text {gap }}\right)$ of molybdenum carbides with and without $\mathrm{Ni}$ were evaluated according to the results obtained by the analysis of diffuse reflectance spectroscopy using the equation proposed by Wood and Tauc [24]. According to this equation, the $\mathrm{E}_{\text {gap }}$ relates the absorbance and energy of the photons by:

$$
\alpha \cdot h \cdot v=\mathrm{A}\left(\mathrm{h} \cdot v-\mathrm{E}_{\text {gap }}\right)^{\mathrm{n}}
$$

where $\alpha$ is the absorbance, $\mathrm{A}$ is a proportionality constant, $\mathrm{h}$ is the Planck constant, $v$ is the frequency, and $\mathrm{n}$ is a variable that depends on the type of the electronic transition, given by $n=1 / 2,2,3 / 2$, or 3 for direct permitted, indirect permitted, direct prohibited, or indirect prohibited, respectively. Since molybdenum carbide presents an indirect electronic transition [28], we considered the value $\mathrm{n}=2$ in Eq. B. Graphs of $(\alpha . h . v)^{1 / 2}, \alpha=\mathrm{F}(\mathrm{R})$, as a function of the photon energy (h.v) for the materials $\mathrm{Mo}_{2} \mathrm{C}, \mathrm{Mo}_{2} \mathrm{C}-$ $\mathrm{Ni} 5 \%$, and $\mathrm{Mo}_{2} \mathrm{C}-\mathrm{Ni} 10 \%$ are shown in Fig. 3. The results
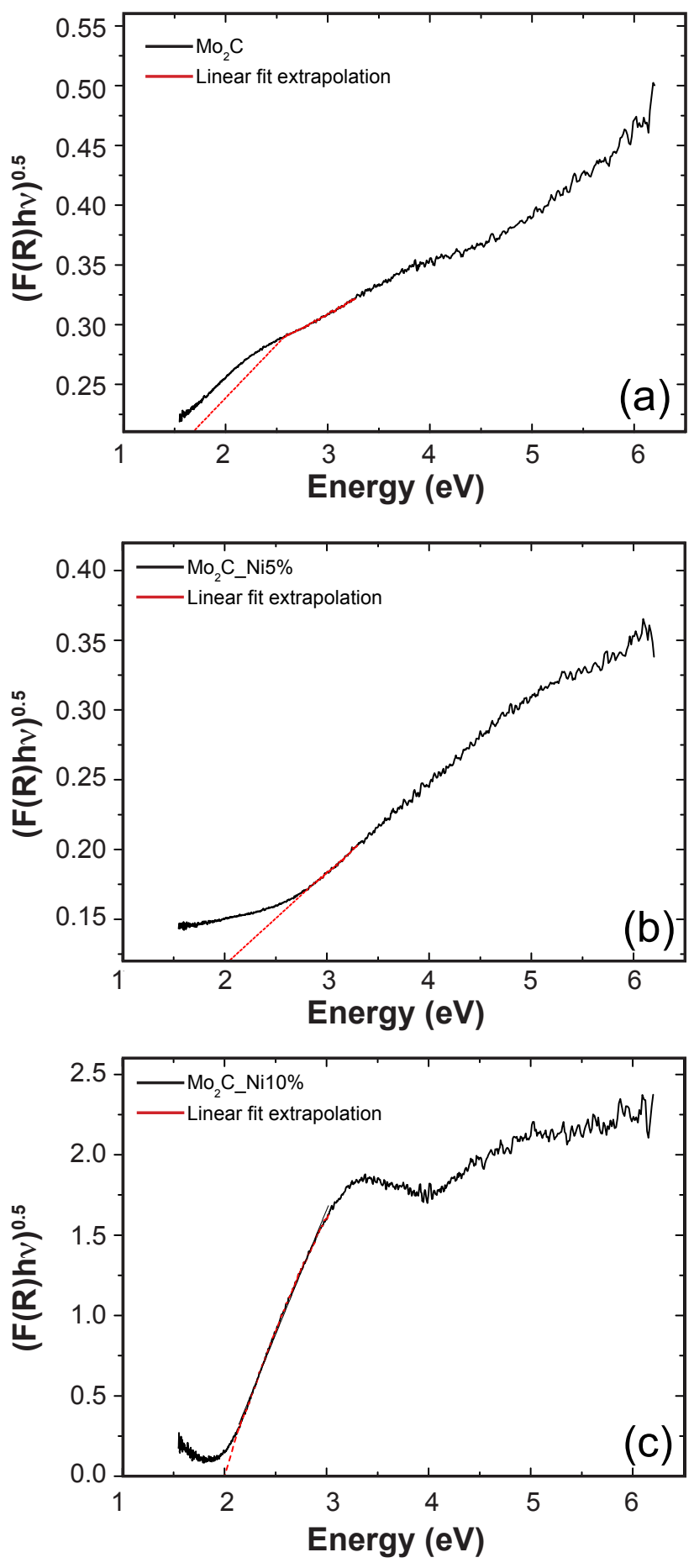

Figure 3: Tauc plots based on diffuse reflectance spectroscopy measurements for the samples: a) $\mathrm{Mo}_{2} \mathrm{C}$; b) $\mathrm{Mo}_{2} \mathrm{C}-\mathrm{Ni} 5 \%$; and c) $\mathrm{Mo}_{2} \mathrm{C}-\mathrm{Ni} 10 \%$.

[Figura 3: Gráficos de Tauc baseados em medidas de espectroscopia de refletância difusa para as amostras: a) $\mathrm{Mo}_{2} \mathrm{C}$; b) $\mathrm{Mo}_{2} \mathrm{C}-\mathrm{Ni} \%$; e c) $\mathrm{Mo}_{2} \mathrm{C}-\mathrm{Ni} 10 \%$.]

of diffuse reflectance spectroscopy measurements of the samples showed the $\mathrm{E}_{\text {gap }}$ values of $1.71,2.02$, and $2.00 \mathrm{eV}$ for $\mathrm{Mo}_{2} \mathrm{C}, \mathrm{Mo}_{2} \mathrm{C}-\mathrm{Ni} 5 \%$, and $\mathrm{Mo}_{2} \mathrm{C}-\mathrm{Ni} 10 \%$, respectively. As reported in [28], the $\mathrm{E}_{\text {gap }}$ of the $\mathrm{Mo}-\mathrm{Mo}_{2} \mathrm{C}$ sample is 1.49 

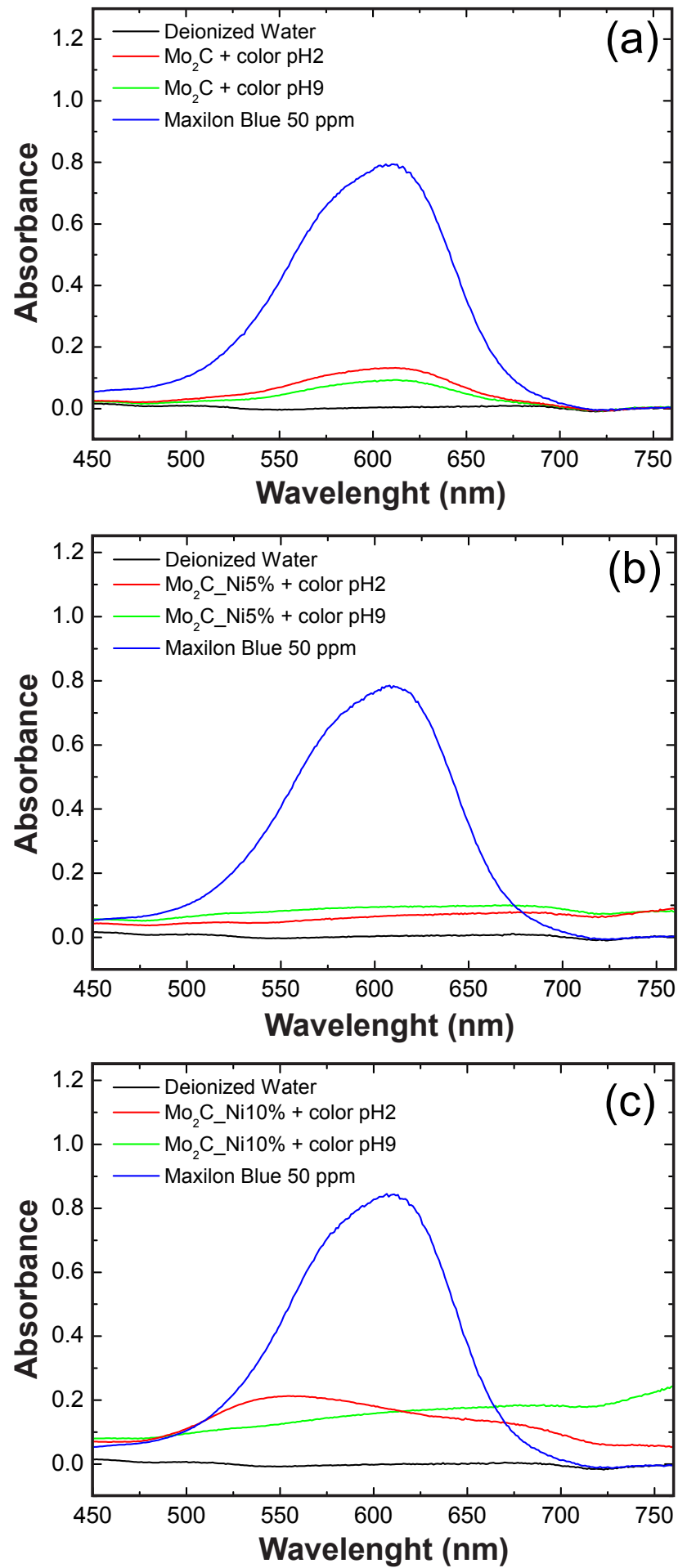

Figure 4: UV-visible spectra after photocatalytic test with Maxilon Blue GRL 300 for: a) $\mathrm{Mo}_{2} \mathrm{C}$; b) $\mathrm{Mo}_{2} \mathrm{C}-\mathrm{Ni} 5 \%$; and c) $\mathrm{Mo}_{2} \mathrm{C}-\mathrm{Ni} 10 \%$.

[Figura 4: Espectros no UV-visível após teste fotocatalítico com Maxilon Blue GRL 300 para: a) $\mathrm{Mo}_{2} \mathrm{C}$; b) $\mathrm{Mo}_{2} \mathrm{C}-\mathrm{Ni} 5 \%$; e c) $\mathrm{Mo}_{2} \mathrm{C}-\mathrm{Ni} 10 \%$.]

$\mathrm{eV}$, stressing that the lower the intensity of this energy, the greater the charge separation efficiency of electron-hole pairs of the photocatalyst. The variation of the band gap energy is directly related to the content and type of dopant
Table II - Concentration values of dye solutions and yields in photocatalytic reaction determined from UV-vis spectra. [Tabela II - Valores de concentração das soluções do corante e rendimentos na reação fotocatalítica determinados a partir dos espectros no UV-vis.]

\begin{tabular}{ccccc}
\hline \multirow{2}{*}{ Sample } & \multicolumn{2}{c}{$\mathrm{pH} 9.0$} & \multicolumn{2}{c}{$\mathrm{pH} 2.0$} \\
& $\begin{array}{c}\text { Conc. } \\
(\mathrm{ppm})\end{array}$ & $\begin{array}{c}\text { Yield } \\
(\%)\end{array}$ & $\begin{array}{c}\text { Conc. } \\
(\mathrm{ppm})\end{array}$ & $\begin{array}{c}\text { Yield } \\
(\%)\end{array}$ \\
\hline $\mathrm{Mo}_{2} \mathrm{C}$ & 6.64 & 86.7 & 4.74 & 90.5 \\
$\mathrm{Mo}_{2} \mathrm{C}-\mathrm{Ni5} \%$ & 4.77 & 90.4 & 3.56 & 92.8 \\
$\mathrm{Mo}_{2} \mathrm{C}-\mathrm{Ni10} \%$ & 8.59 & 82.8 & 8.42 & 83.2 \\
Error $(\%)$ & 1.10 & 2.19 & 1.46 & 2.89 \\
\hline
\end{tabular}

added to the matrix. From the XRD analysis, there was a decrease in the intensity of the main peak with the addition of the dopant, resulting in changes in the $\mathrm{E}_{\text {gap }}[29,30]$. Also, the occurrence of molybdenum carbide structure change from orthorhombic to hexagonal leads to a change in the $\mathrm{E}_{\text {gap }}$ value. Our results were in accordance with that report in [31], in which the hexagonal structure of the molybdenum carbide shows an $\mathrm{E}_{\text {gap }}$ value of around $1.05 \mathrm{eV}$.

The $\mathrm{E}_{\text {gap }}$ is associated with the presence of intermediate energy levels within the material gap. These intermediate energy levels depend on the order-disorder degree of the crystalline structure of the material, indicating that the increase of the structural organization within the grid leads to a reduction of the intermediate energy levels and, consequently, $\mathrm{E}_{\text {gap }}$ increases. In this regard, we can explain the increase in the $\mathrm{E}_{\text {gap }}$ value of $\mathrm{Mo}_{2} \mathrm{C}$ in relation to that found in the literature. This organization's degree is associated with the synthesis method in the production of molybdenum carbide [29, 30]. It should be noted that the presence of nickel in the molybdenum carbide structure causes changes in the band gap values and may be related to the change in the morphology of the doped materials [24]. The $\mathrm{E}_{\text {gap }}$ variation can be explained by distinct factors such as: particle morphology, synthesis method, shape (thin film or powder), annealing temperature, and processing time [29]. These factors led to different structural defects in the crystalline network of the sample, such as oxygen vacancies and network distortion, which are capable of promoting the formation of intermediate energy levels within the gap [30]. According to the literature, in the diffuse reflectance study, $\mathrm{Mo}_{2} \mathrm{C}$ presented a band gap energy of $1.1 \mathrm{eV}$ [29]. In another study, the $\mathrm{Mo}_{2} \mathrm{C}$ presented a band gap energy of $3.85 \mathrm{eV}$. This difference in $\mathrm{E}_{\text {gap }}$ values is associated with the degree of organization of the crystal structure of molybdenum carbide material [30].

Photocatalysis characterization: to determine the reaction time (RT) and $\mathrm{pH}$ solution for our samples, studies varying the RT from 1 up to $5 \mathrm{~h}$ for distinct $\mathrm{pH}$ solution $(2.0,7.0$, and 9.0) were performed. From these results, we established that the reaction time of $1.0 \mathrm{~h}$ and the $\mathrm{pH}$ of the solution at 2.0 and 9.0 were the optimal parameters for the study. The representative results of photocatalytic degradation 
of the Maxilon Blue GRL 300 textile dye in the presence of the molybdenum carbide catalyst at different reaction times and $\mathrm{pH}$ of the solution showed a strong decrease in absorbance at low reaction time values, followed by nearconstant value as the reaction time increased. Similar results were observed for the samples with distinct $\mathrm{pH}$ values. Fig. 4 shows the UV-visible spectra for the carbide tested $\left(\mathrm{Mo}_{2} \mathrm{C}\right.$ and $\mathrm{Mo}_{2} \mathrm{C}-\mathrm{Ni}$ ) in $50 \mathrm{ppm}$ dye solutions at $\mathrm{pH} 2.0$ and 9.0 in the presence of tungsten light. The solutions were analyzed with and without carbide-type materials in order to compare the absorbance results found after the reaction time of 1.0 $\mathrm{h}$, so it was verified the decrease in the concentration of the dye solution from the $50 \mathrm{ppm}$ concentration matrix solution. With the results obtained in the spectroscopy analysis in the UV-visible region, it was possible to calculate the final concentrations and yields of each solution after a reaction time of $1 \mathrm{~h}$ for $\mathrm{Mo}_{2} \mathrm{C}, \mathrm{Mo}_{2} \mathrm{C}-\mathrm{Ni} 5 \%$, and $\mathrm{Mo}_{2} \mathrm{C}-\mathrm{Ni} 10 \%$; these values are listed in Table II.

The principle and mechanism of photocatalysis have been discussed $[13,15,19]$. The irradiation of $\mathrm{Mo}_{2} \mathrm{C}$ and $\mathrm{Mo}_{2} \mathrm{C}-\mathrm{Ni}$ by a light source caused the excitation of the electrons located in the valence band to the conduction band. As a result, holes $\left(\mathrm{h}^{+}\right)$and electrons ( $\left.\mathrm{e}^{-}\right)$were generated in the valence and conduction bands, respectively. The generated $\mathrm{h}^{+}$was derived from the hydroxyl radicals in reaction with water. These hydroxyl radicals caused the degradation of organic molecules, often from dyes. The photogenerated electrons were attached to oxygen in the form of superoxide radicals and subsequent conversion to hydroxyl radicals. Usually, the efficiency of photocatalysts is characterized by factors such as the adsorption capacity, the electronhole pair production, and the recombination time of the electron-hole pair. The latter has an important factor in the overall performance of the photocatalyst material [19]. The photocatalysis process, with activation through visible light for various materials, such as $\mathrm{Mo}_{2} \mathrm{C}$, was studied in distinct reports [32-34], demonstrating the efficiency of this process for $\mathrm{H}_{2}$ evolution.

The photocatalytic activity measured for all samples showed a considerable reduction in the final concentrations of the dye solutions, compared to the initial $50 \mathrm{ppm}$ solution, both in acidic and basic media. For the samples of $\mathrm{Mo}_{2} \mathrm{C}$ and $\mathrm{Mo}_{2} \mathrm{C}-\mathrm{Ni} 5 \%$, we observed higher reaction yields in comparison with $\mathrm{Mo}_{2} \mathrm{C}-\mathrm{Ni} 10 \%$. In particular, the $\mathrm{Mo}_{2} \mathrm{C}$ sample showed the same level of conversion compared to $\mathrm{Mo}_{2} \mathrm{C}-\mathrm{Ni} 5 \%$, considering the calculated error range. For the $\mathrm{Mo}_{2} \mathrm{C}-\mathrm{Ni} 10 \%$ sample, it can be considered that there was a limit to the bulk quantity of dopant for the activation of the material and dye degradation occurring in both acidic and basic environments. The carbides studied in this paper had the characteristic of nanometric materials, proved by the analysis of crystallite size, which added ease of dispersion in the solution, causing difficulties in removing them from the suspension, which may have impaired the UV-visible analysis; even if the samples were centrifuged, there would still be particles in suspension. In general, we can say that the photocatalytic behavior of the samples is connected with the structural characteristics of the materials. The insertion of Ni-dopant in the $\mathrm{Mo}_{2} \mathrm{C}$ structure, identified through XRD analysis, increased the formation of particle clusters (see SEM images), causing an increase in the band gap energy of the materials. Therefore, it positively influenced the photocatalytic degradation of the dye.

\section{CONCLUSIONS}

The process of producing Ni-doped molybdenum carbides in a fixed bed reactor proved to be efficient. According to the results obtained through XRD and SEM analyses, it was possible to observe the presence of the characteristic peaks of $\mathrm{Mo}_{2} \mathrm{C}$ in all samples and the change in the morphology of the particle agglomerates with the addition of Ni. The mean crystallite size calculations indicated that the particles had nanometer sizes ranging from 34.7 to $37.5 \mathrm{~nm}$, calculated by the HWL method from the X-ray diffraction peaks. The Maxilon Blue GRL 300 was degraded upon irradiation with tungsten light in the presence of all catalysts. Tests carried out in both acidic and basic $\mathrm{pH}$ demonstrated the efficiency of the photocatalysis process for the synthesized carbides, achieving a removal performance of up to $92 \%$ at the final concentration of the dye. This study revealed a new system of a low-cost catalyst with potential application in the photocatalytic degradation of dyes.

\section{ACKNOWLEDGMENTS}

The authors thank the financial support of the Brazilian research financing institutions: CETENE/FACEPE for granted scholarship and performance of the XRD analysis; PPGEQ, PPGCEM for the analysis of diffuse reflectance spectroscopy, NUPEG for the UV-vis analyzes and UFRN, CNPq, and CAPES for the financial assistance.

\section{REFERENCES}

[1] G. Vitale, H. Guzmán, M.L. Frauwallner, C.E. Scott, P.P. Almao, Catal. Today 250 (2015) 123.

[2] J.R.S. Polliti, F. Vines, J.A. Rodriguez, F. Illas, Phys. Chem. Chem. Phys. 15 (2013) 12617.

[3] A.A. Smirnov, Z. Geng, S.A. Khromova, S.G. Zavarukhin, O.A. Bulavchenko, A.A. Saraev, V.V. Kaichev, D.Y. Ermakov, V.A. Yakovlev, J. Catal. 354 (2017) 61.

[4] S. Tuomi, R. Guil-Lopez, T. Kallio, J. Catal. 334 (2016) 102.

[5] A.S. Rochab, A.B. Rochab, V. Teixeira da Silva, Appl. Catal. A Gen. 379 (2010) 54.

[6] A. Szyman'ska-Kolasa, M. Lewandowski, C. Sayag, D. Brodzki, G. Djéa-Mariadassou, Catal. Today 119 (2006) 35. [7] A.M. Stux, C. Laberty-Robert, K.E. Swider-Lyons, J. Solid State Chem. 181 (2008) 2741.

[8] G. Jin, J. Zhu, X. Ventilador, G. Sun, J. Gao, Chinese J. Catal. 27 (2016) 899.

[9] Y. Miyamoto, M. Akiyama, M. Nagai, Catal. Today 146 (2009) 87. 
[10] R.P.F. Melo, E.L. Barros Neto, M.C.P.A. Moura, T.N. Castro Dantas, A.A. Dantas Neto, H.N.M. Oliveira, Sep. Purit. Technol 138 (2014) 71.

[11] B. Baruah, L. Downer, D. Agyeman, Mat. Chem. Phys. 231 (2019) 252.

[12] Y. Li, J. Li, X. Wang, Y. Ma, W. Guan, T. Qian, Mat. Chem. Phys. 182 (2016) 402.

[13] G. Halasi, T. Bansagi, E. Varga, F. Solymosi, Catal. Lett. 145 (2015) 875.

[14] Y. Xu, R. Xu, Appl. Surf. Sci. 351 (2015) 779.

[15] S. Izhar, M. Nagai, J. Power Sources 182 (2008) 52.

[16] S.L.A. Dantas, A.L. Lopes-Moriyama, C.P. Souza, Mat. Chem. Phys. 216 (2018) 243.

[17] F.F.P. Medeiros, S.A. Oliveira, C.P. Souza, A.G.P. Silva, U.U. Gomes, J.F. Souza, Mat. Sci. Eng. A 315 (2001) 58.

[18] S.B. Atla, W. Lin, T. Chien, M. Tseng, J. Shu, C. Chen, C. Chen, Mat. Chem. Phys. 216 (2018) 380.

[19] H.A. AL-Megren, T. Xiao, S.L. Gonzalez-Cortes, S.H. Al-Khowaiter, M.L.H. Green, J. Mol. Catal. A Chem. 225 (2005) 143.

[20] A.A. Mazilkin, B.B. Straumal, A.R. Kilmametov, T. Boll, B. Baretzky, O.A. Kogtenkoya, A. Korneva, P. Zieba, Scr. Mater. 173 (2019) 46.

[21] Y. Ivanisenko, X. Sauvage, A. Mazilkin, A. Kilmametov, J.A. Bach, B.B. Straumal, Adv. Eng. Mater. 20 (2018) 1800443.

[22] B.B. Straumal, A.A. Mazilkin, S.G. Protasoya, A.A. Myatiev, P.B. Straumal, B. Baretzky, Acta Mater. 56 (2008) 6246.
[23] S.L.A. Dantas, A.L.R. Souza, F. Bohn, A.L. LopesMoriyama, C.P. Souza, M.A. Correa, Mater. Lett. 273 (2020) 127916.

[24] X. Yue, S. Yi, R. Wang, Z. Zhang, S. Qiu, J. Mater. Chem. A 21 (2017) 10591.

[25] Y. Yao, Y. Hu, M. Yu, C. Lian, M. Gao, J. Zhang, G. Li, S. Wang, Chem. Eng. J. 344 (2018) 535.

[26] M.A. Hamdan, S. Loridant, M. Jahjah, C. Pinel, N. Perret, Appl. Catal. A Gen. 571 (2019) 71.

[27] N.S. Gonçalves, J.A. Carvalho, Z.M. Lima, J.M. Sasaki, Mater. Lett. 72 (2012) 36.

[28] J. Dong, Y. Shi, C. Huang, Q. Wu, T. Zeng, W. Yao, Appl. Catal. B 243 (2019) 27.

[29] J.C. Sczancoski, L.S. Cavalcante, M.R. Joya, J.W.M. Espinosa, P.S. Pizani, J.A. Varela, E. Longo, J. Colloid Interf. Sci. 330 (2009) 227.

[30] L.S. Cavalcante, V.M. Longo, J.C. Sczancoski, M.A.P. Almeida, A.A. Batista, J.A. Varela, M.S. Li, CrystEngComm 14 (2012) 853.

[31] X. Yue, S. Yi, R. Wang, Z. Zhang, S. Qiu, Nano Energy 47 (2018) 463.

[32] H. Liu, J. Yu, Y. Chen, Z. Zhou, G. Xiong, L. Zeng, H. Li, Z. Liu, L. Zhao, J. Wang, B. Chu, H. Liu, W. Zhou, ACS Appl. Mater. Interfaces 12 (2020) 2362.

[33] L. Yang, L. Zeng, H. Liu, Y. Deng, Z. Zhou, J. Yua, H. Liu, W. Zhou, App. Catal. B 249 (2019) 98.

[34] J. Jia, T. Xiong, L. Zhao, F. Wang, H. Liu, R. Hu, J. Zhou, W. Zhou, S. Chen, ACS Nano 11 (2017) 12509.

(Rec. 17/03/2020, Rev. 22/05/2020, Ac. 12/06/2020) 